\title{
Creation and the revelation of God's children: Liberation of enslaved bodies
}

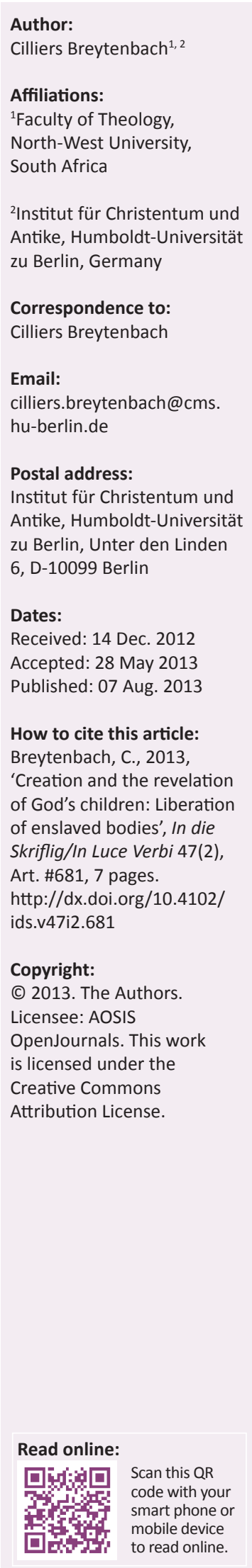

In the first part of the article the role of Romans 8:18-30, within Romans 5:1-8:39, is briefly discussed. In the second part a summary of the argument of Romans 7:7-17, as presupposition for the understanding of Romans 8:18-30, is given. In the third part a close reading of Romans 8:18-30 is given, followed by concluding remarks. The article illustrates that Paul's line of thought moves from the future transformation of the believers to the transformation of the creation.

Skepping en die openbaring van God se kinders: Die bevryding van die verknegde liggaam In die eerste deel van die artikel word die rol van Romeine 8:18-30 as deel van Romeine 5:1-8:39, kortliks bespreek. In die tweede deel word 'n samevatting van die argument van Romeine 7:7-17 gegee - dit is die voorveronderstelling om Romeine 8:18-30 te verstaan. In die derde deel word 'n noukeurige uitleg van Romeine 8:18-30 gegee, gevolg deur slotopmerkings. Die artikel illustreer dat Paulus, op grond van die toekomstige transformasie van die gelowiges, afsluit met die idee dat die skepping volkome verander sal word.

\section{Introduction: Romans 8:5-30 within Romans 5:1-8:31}

When one thinks of Paul and the world, one normally recalls Romans 8:18-30 first. A closer look reveals that the text does not point in the direction of cosmology, ${ }^{2}$ but nevertheless expresses Paul's thought about the future of creation:

The forward leaning expectancy of the creation awaits the revelation of the sons of God, for the creation has been subjected to purposelessness ... Creation itself will be liberated from the bondage of decay. (Rm 8:19-20)

This text is not about the cosmos, but on creation. But is there such a big difference? With the

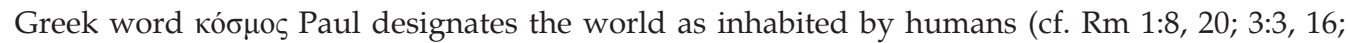

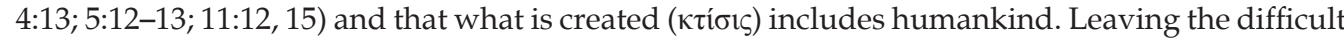

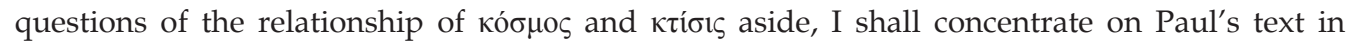
Romans, focusing on Romans 8:18-30.

In the second main part of his letter to the Romans (Rm 5:1-8:39), Paul explains what the justification of the sinners implies. The whole argument is framed by Romans 5:1-11 and 8:31-39, and the recurrence of several topics has been noted by various scholars since Dahl's seminal essay. ${ }^{3}$ One vital intention is to assure the addressees that their justification as formerly impious sinners, or alternatively the changing of God's enemies into his friends (i.e. reconciliation ${ }^{4}$ ), will end in their rescue from the wrath of God ( $R m$ 5:6-10). The current state of being justified or reconciled was brought about by the trust in the effect of the death of Christ as proclaimed in the gospel. ${ }^{5}$ Ending the section in Romans 8:31-39, Paul repeats this assurance. Since God has delivered his own Son for the sake of 'all of us', those who are trusting in God's gospel about the death and resurrection of Jesus Christ need not fear final judgment. Their hope to be acquitted is not in vain. Paul has, however, a second intention. His focus is not on the future salvation only. In Romans 5:1-5 he focuses on the present. He and his addressees already stand firm in the favour ${ }^{6}$ of God and take pride on the basis of their hope which anticipates the ' $\delta$ ' $\xi \alpha$ of God'. They

\footnotetext{
1.I here draw on material presented at the 22nd meeting of the Colloquium Oecumenicum Paulinum in Rome in 2012 that will be published in the conference proceedings in Série Monographique de Benedictina (Leuven: Peeters)

2.Jewett (2007:viii, 478) speaks of a 'cosmic struggle between flesh and spirit' and 'the cosmic context of suffering' (p. 507). Vögtle (1970) already warned against underplaying the anthropological-soteriological aspects of the text.

3.Cf. Dahl (1951). For the discussion since Dahl and additional aspects, cf. Eschner (2009:659-662).

4.For this interpretation of $\kappa \alpha \tau \alpha \lambda \lambda \alpha \dot{\sigma} \sigma \sigma \omega, \mathrm{cf}$. Breytenbach (2010a).

5.Cf. Eschner (2009).
}

6.For the reasons of the translation with favour, cf. Breytenbach (2010b). 
express their confidence loudly in contrast to their current circumstances, a topic Paul reintroduces in Romans 8:17. In Romans 5:3 he states that in tribulation they are proud, knowing that affliction also gives the opportunity to endure the oppression and that perseverance enables one to stand the test. This validation in turn promotes hope, and this anticipation will not be disappointed. Why will the hope not

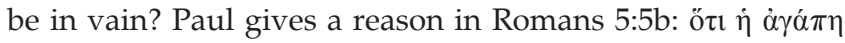

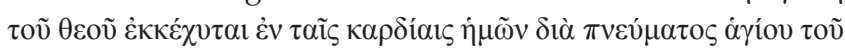

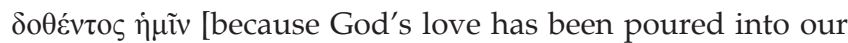
hearts through the Holy Spirit that has been given to us]. In Romans 8:9-17 he takes up this topic and elaborates on it.

In the first section of his argument (Rm 5:12-21), after the introductory passage (Rm 5:1-11), Paul compares the favour of God, in which the believers now stand firmly, to the power of sin. Since the grace of God that leads to the justification exceeds $\sin$, he poses the question whether this would allow those who believe in Christ to continue sinning. By explaining the consequences of being baptised into Christ's death, he sharply refutes such behaviour in the second section of his elaborations ( $\operatorname{Rm~6:1-7:6).~}{ }^{7}$ Within his argument, he returns

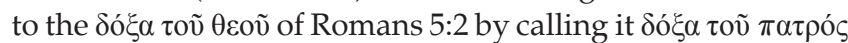
(Rm 6:4). The believers take pride, on the basis of hope, to experience the $\delta$ ó $\xi \alpha$ of God - the same $\delta$ ó $\xi \alpha$ through which Christ was resurrected from the dead. Those believing in the gospel were baptised into Christ's death in order that, in analogy to the resurrected Christ, they can live a new life (Rm 6:4b). In baptism they already shared the experience of his death; in future they will share the experience of his resurrection (Rm 6:5). From Romans 8:9-11 onwards, Paul develops his idea of the interconnectedness of the believers with the Spirit of God who resurrected Christ in more detail.

\section{Romans 7:7-8:17 as presupposition for the interpretation of Romans 8:18-30}

At the beginning of the third section ( $\operatorname{Rm} 7: 7-8: 17)$ of the argument, Paul first clarifies the relation between sin and the Thora. The latter is good and holy and leads to the recognition of sin, but the power of sin is so overwhelming that the commandment, which is good, incites the sinful deed leading to death. In this way sin becomes known. In Romans 7:14-8:4, Paul returns to his main argument. How are humans freed from the captivity by $\sin$ ? Man is sold to sin and is like a slave. He or she is not free, but under command of the owner, sin. Romans 7:21 and 23 are of particular interest, since Paul specifies the slave imagery as being taken as prisoner of war. Even though man delightfully agrees with the Law (Thora) of God, he is held as prisoner of war ( $\alpha i \chi \mu \alpha \lambda \omega \tau i \zeta \omega)$ by the law affected by sin. In his body parts, this affected law wages war ( $\left.\dot{\alpha} v \tau 1 \sigma \tau \rho \alpha \tau \varepsilon v u_{0} \mu \imath\right)$ against (the real intention of) the Law of God on which man has set his mind. Human beings are not free to do as they wish, they are captives of sin. In Romans 7:24 Paul laments: 'Wretched man that I am! Who will rescue

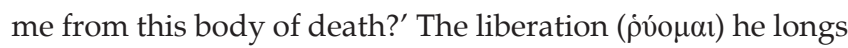

7.Some expositors take Romans $6: 1-23$ and $7: 1-25$ as units; cf. Käsemann (1974), Cranfield (1975), Lohse (2003). for is the freedom of the body which is subjected to death ( $\dot{\varepsilon} \kappa$

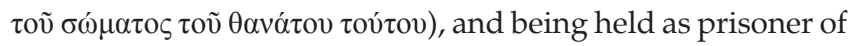
war by the sin-affected law.

Paul brings the argument of Romans 7:7-25 to a close in Romans 8:1-4. In Romans 8:3, Paul explains how God convicted $\sin$ in the weak human flesh of Christ. This is why he can claim that there is no condemnation for those who are in Christ ( $\mathrm{Rm} \mathrm{8:1).} \mathrm{The} \mathrm{law} \mathrm{of} \mathrm{the} \mathrm{Spirit,} \mathrm{which} \mathrm{brings} \mathrm{life}$ in Jesus Christ, freed them from the Thora that was under the power of $\sin$ and thus led to death. But we have to wait until Romans 8:23 to learn how the bodies of those who live according to the Spirit (v. 4) will be freed. This is the main line of argumentation developed in Romans 8:18-30: the liberation of the enslaved body.

The fourth section ( $\mathrm{Rm}$ 8:5-17) formulates several presuppositions important for the understanding of verses 18-30. In Romans 8:5 to 9, Paul develops the opposition between $\sigma \alpha \dot{\rho} \xi \xi$ and $\pi v \varepsilon \tilde{v} \mu \alpha$ he introduced in verse 4 . The

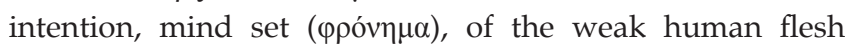
is against God and leads to death. Those who are $\dot{\varepsilon} v$ баркí cannot win God's favour. However, since the Spirit of God lives in the addressees, they are not 'in the flesh'. Of course he does not deny bodily existence (Gl 2:20), but they are no longer reigned by the flesh. The next step Paul takes presupposes that the Romans have the Spirit, since they do belong to Christ. Paul develops the ethical aspect of being in the Spirit. ${ }^{8}$ In the current context it is crucial to understand Romans 8:10 and 11. Even under the condition of having the Spirit, and thus Christ, in them, the human body stays dead because of the $\sin .{ }^{9}$ In contrast to the dead body, the human spirit of those having Christ in them is life, since they have been justified. This is the current situation. In Romans 8:11, Paul calls the bodies of those having the Spirit not dead

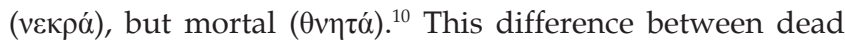
and mortal refers back to Romans 6. Paul has argued that those baptised into Christ's death died with him (Rm 8:8a, 11). The body was crucified with Christ in baptism in order

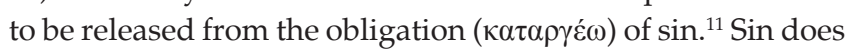
not rule over the body anymore (Rm 6:6b). The baptised are

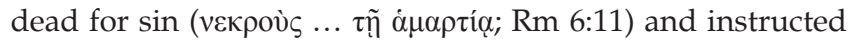
that they are not to let sin rule in their mortal bodies ( $\dot{\varepsilon} v \tau \tilde{\varphi}$ $\theta v \eta \tau \tilde{\omega} \dot{v} \mu \tilde{\omega} v \sigma \omega \mu \alpha \tau 1 ; R m$ 6:12a). The theme of the mortal body is reintroduced in Romans 8:11. Paul still argues under the condition that the addressees have the Spirit in them, but he

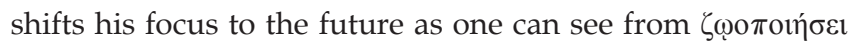
(Rm 8:11). The $\pi v \varepsilon v ́ \mu \alpha \tau \alpha$ of the Romans are already a means of life, because the Spirit of God lives in them (Rm 8:9-10), but God will also make their mortal bodies alive through the same Spirit by which he resurrected Christ from the 8.Cf. also Zeller (1985:150)

9.The causal interpretation of both $\delta i \alpha$ and accusative phrases is to be preferred, as most commentators do.

10.According to Romans $6: 6$, the body qualified by $\sin$ was destroyed in baptism, but man still lives in the mortal body ( $\mathrm{Rm} \mathrm{6:12).}$

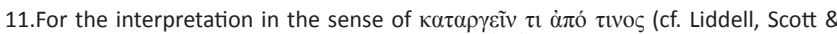
Jones 1996 and Bauer et al. 2000, s.v.), cf. the áró in Romans 6:7 and 7:2b. 
dead. This situation of the believers (their $\pi v \varepsilon \tilde{u} \mu \alpha$ 'alive' and their bodies mortal, but due to be vivified) has important implications for their current lifestyle. Paul develops this in Romans 8:12-17.

Those who are of Christ are not obliged to live according to the $\sigma \alpha \dot{\alpha} \rho \xi$ - if they do, they will die. By implication, they are under obligation to live according to the Spirit. Through the Spirit they have to kill the deeds of the body. Paul reassures the addressees that the Spirit of God, which they have already received, guarantees that they are already adopted by God as his children. As in the case of the homologia that Christ is Lord (1 Cor 12:3), it is through the Spirit that they can call God 'Father' and expect to be his heirs, together with God's own Son. Together with the resurrected Son they will be glorified. What Paul means when he says that the children of God will be glorified with Christ, has to be clarified within the context of Romans 8:18-30, to which we now turn. Paul argues that, now that sin has been condemned in the Son and the believers have been given the Spirit, they will become like the risen Son $(\operatorname{Rm} 8: 29)$.

\section{Analysis of Romans 8:18-30}

The rest of Paul's argument can be divided into three more subsections. In the first part (Rm 8:18-21), Paul comments on his statement in Romans 8:17c. There he concludes that if he and his addressees are children of God, then they are also heirs - heirs of God and joint heirs with Christ. If, in fact, they currently suffer with Christ, they may also be 'glorified' with him in future. I put the word glorified in inverted commas, because it is crucial to clarify what $\sigma v v \delta o \xi \alpha \dot{\alpha} \omega$ and $\delta$ ó $\xi \alpha$ mean and to what Paul referred when using these words in Romans 8.

In Romans 8:18, Paul gives his opinion on the present suffering

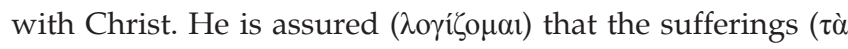
$\pi \alpha \theta \eta \mu \alpha \tau \alpha)$ of this present time are not worthy of comparison to $^{12}$ the $\delta$ ó $\xi \alpha$, that is 'about to be' $\left(\mu \varepsilon \lambda^{\prime} \lambda \sigma o v \sigma \alpha\right)^{13}$ uncovered by God. The $\delta$ ó $\xi \alpha$ is - albeit currently still undisclosed - with

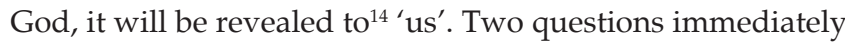

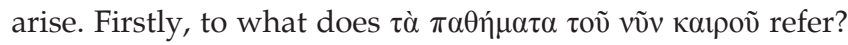
Secondly, what is meant by 'the $\delta$ ó $\xi \alpha$ about to be revealed to us'? Both questions can be answered by referring to what Paul has dictated up to this point. In Romans 5:2 he already remarked that he and his auditors boast on the basis of the

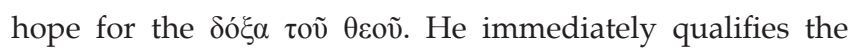

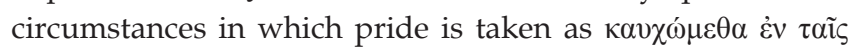
$\theta \lambda i \psi \varepsilon \sigma ı v$ (Rm 5:3); $\theta \lambda \tilde{i} \psi 1 \varsigma$ being distress that is brought about by outward circumstances. ${ }^{15}$ There is no indication that Paul refers to specific circumstances of the Roman believers. ${ }^{16}$

12.For this use of $\pi \rho \varsigma_{\varsigma}$, cf. Blass, Debrunner and Rehkopf $2001 \S 239_{8}$.

13.Cf. Blass et al. $2001 \S 356_{4}$

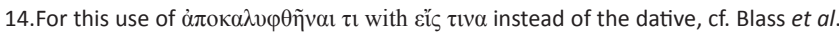
$2001 \S 207_{2}$.

15.Cf. Bauer et al. 2000, s.v.

16.See Jewett (2007:509).
What is meant by $\delta$ ó $\xi \alpha$ ? Before we simply translate the Greek word to 'glory', it might help us to remember what we have read up till now. In Romans 5:2-3 Paul took up an opposition he had already introduced in Romans 2:9-10 - between $\theta \lambda \tilde{\imath} \psi 1 \varsigma$ and $\sigma \tau \varepsilon v 0 \chi \omega \rho i ́ \alpha$ on the one hand and $\delta$ ó $\xi \alpha$ on the other. The contrast between current suffering and future $\delta$ ó $\xi \alpha$ are repeated in Romans 8:17-18. As he and the Romans, listening to the reading of his letter, are suffering with Christ, they will also be approved together ${ }^{17}$ with him (Rm 8:17):

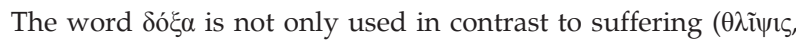

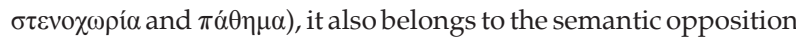
'honour' and 'shame', as can be seen from 1 Corinthians 4:10:

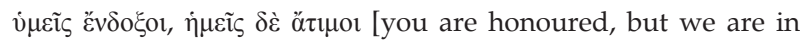
disrepute]. Its opposite can be $\kappa \varepsilon v o \delta o \xi i ́ \alpha$, [empty honour] (Phlp

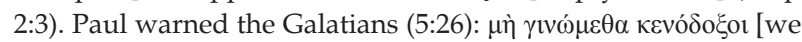
should not become falsely proud]. But which components of meaning does the word $\delta$ ó $\xi \alpha$ entail positively? It combines with

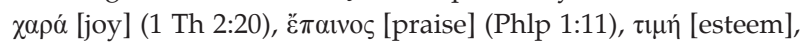

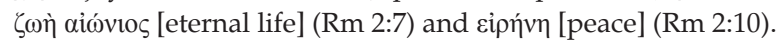

In Romans, $\delta$ ó $\xi \alpha$ refers to a specific quality attributed to God as imperishable in contrast to his creatures that are subject to decay ( $\mathrm{Rm}$ 1:23). This is why Paul formulates in Romans 6:4 that Christ has been raised from the dead by the $\delta$ ó $\xi \alpha$ of the

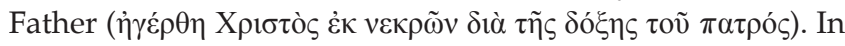
Romans 8:19 Paul gives the reason for his statement in verse 18. ${ }^{18}$ The subject of the sentence, $\dot{\eta} \dot{\alpha} \pi$ ок $\alpha \alpha \delta$ oкí $\alpha$, is used in Christian texts only: ${ }^{19}$

The verb $\dot{\alpha} \pi$ ок $\alpha \rho \alpha \delta \circ \kappa \varepsilon^{20}$ is used more widely. ${ }^{21}$ Aquila $^{22}$, Josephus $^{23}$ and Polybius ${ }^{24}$ used it to express the state of waiting to see what is going to happen and it is probably an intense

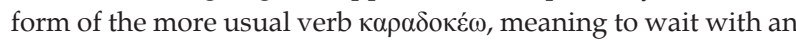
outstretched head. ${ }^{25}$ The meaning of the noun is less clear. The Suda and Hesychius interpret it with $\pi \rho$ оббокía, thus deriving

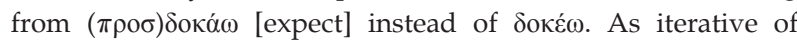
$\delta \varepsilon ́ \chi 0 \mu \alpha 1, \delta$ бќ் can also have the meaning 'to expect', but the focus is more on 'think, suppose, imagine'. ${ }^{26}$

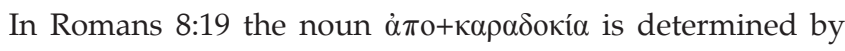
$\tau \tilde{\eta} \varsigma \kappa \tau i ́ \sigma \varepsilon \omega \varsigma$ and the expression should be explained as a unit. The somewhat metaphorical phrase ả express something like 'the forward leaning expectancy of the creation' ${ }^{27}$ Paul is using language that personifies creation. Here he refers to the whole of creation, juxtaposing it to the 17.For this meaning of $\sigma 0 v \delta \circ \xi \alpha \zeta \varepsilon \sigma \theta \alpha$, cf. Liddell et al. 1996, s.v.

18.Romans 8:19-23 are part of the Pauline argument and cannot for ecotheological reasons be isolated and treated as a narrative; pace Hunt, Horrell and Southgate (2008).

19.Cf. Origen, Contra Celsum 7.65; 8.15; Commentarii in evangelium loannis 1.26.170.

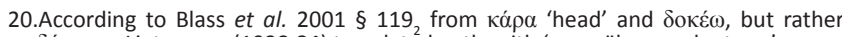
$\delta \varepsilon ́ \chi 0 \mu \alpha$. Lietzmann $(1928: 84)$ translated aptly with 'ausspähen nach etwas'.

21.Cf. Bauer et al. 2000, s.v.

22.Cf. $P s^{\alpha \prime} 36: 7$.

23.Cf. Josephus, Bellum Judaicum 3.264.

24.Cf. Polybius, Historiae 16.2.8; 18.48.4; 21.36.3, and Mauersberger (1956, s.v.)

25.Cf. Liddell et al. 1996, s.v.

26.Cf. Liddell et al. 1996, s.v.

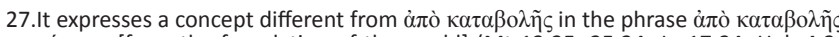

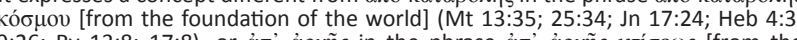

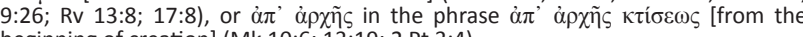
beginning of creation] (Mk 10:6; 13:19; 2 Pt 3:4). 
children of God..$^{28}$ The creation expects the uncovering of the sons of God as eagerly as a human protruding his head in expectancy to see what will happen. ${ }^{29}$ But the children of God

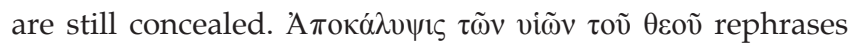

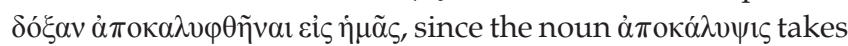
up the verb $\dot{\alpha} \pi$ ок $\alpha \lambda v \varphi \theta \tilde{\eta} v \alpha$ and the expression sons of God refers to the same group as the pronoun us. Consequently, the unveiling of the sons of God also entail that they will receive $\delta$ ó $\xi \alpha$. What does this mean?

Romans 8:20 explains the statement of verse 19. The forward stretching expectancy of the creation awaits the revelation of the sons of God, because the creation was subjected to purposelessness ( $\mu \alpha \tau \alpha$ ió $\left.\eta_{\zeta}\right)$. The Greek word expresses the state of being without use or value ${ }^{30}$ (like idle talk) $)^{31}$ and might have come to Paul via Israelite-Jewish wisdom:

Psalms ${ }^{\mathrm{LXX}} 38: 6$ expresses the idea that human life is purposeless, ${ }^{32}$ and Psalms ${ }^{\mathrm{LXX}}$ 77:33 that the lives of those punished by God end $\dot{\varepsilon} v \mu \alpha \tau \alpha$ ó $\tau \tau \tau .{ }^{33}$ It might have been the refrain from Ecclesiastes

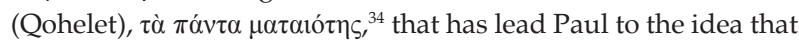
creation is subjected to $\mu \alpha \tau \alpha$ เótๆs.

After foregrounding subjection of the creation to futility, Paul qualifies with an ov̉ ... $\dot{\alpha} \lambda \lambda \dot{\alpha}$ construction $\dot{v} \pi \varepsilon \tau \dot{\alpha} \gamma \eta$

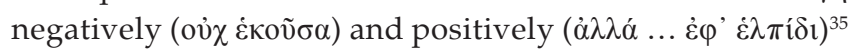
and explains that the creation is not willingly subjected (ov $\chi$ $\dot{\varepsilon} \kappa o v \tilde{\sigma} \alpha)$, but $\operatorname{God}^{36}$ subjected it in hope, in anticipation. Paul

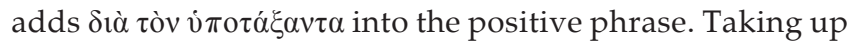
the line of argumentation from Romans 5:12-21, he explains that creation is subjected (perfect passive) because of him ${ }^{37}$ (i.e. God) who subjected it (aorist). Normally it is said that

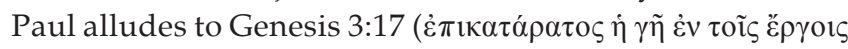

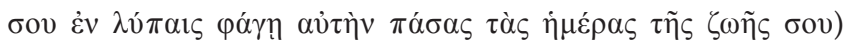
and Genesis 5:29. According to 4 Ezra 7:12-13, another text often used to explain Romans 8:20, Adam's sin made the ways of this world narrow, sorrowful, painful and full of

28.Early patristic evidence (cf. Kuss 1963:622-623) included humankind under the

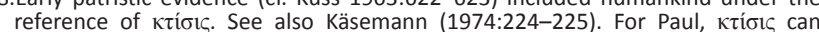
refer to humans (2 Cor 5:17; Gl 6:15), include humans (Rm 8:19-20, 39) or the

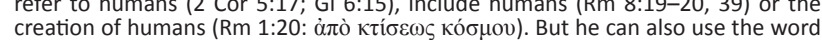

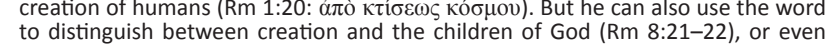

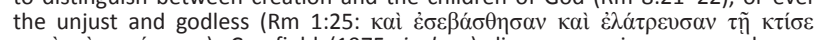

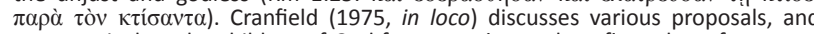
wants to isolate the children of God from creation and confines the reference to the subaltern world. This is not necessary, since presently the children of God are also subjected to decay (cf. Rm 8:10; 1 Cor 15:50-51). Here in Romans 8:22, ktíøı focuses on non-human creation, but this does not mean that, for Paul, humanity is not also subjected to decay. For a review of early interpretations of $\kappa \tau i \sigma i \varsigma$, cf. Hunt et al. (2008:547-549).

29.Cf. Bertram (1958:265).

30.Cf. Ephesians 4:17; Jos. Asen. 21:19.

31.Cf. Psalms ${ }^{\text {Lx }} 143: 11 ;$ Jos. Asen. 21:19.

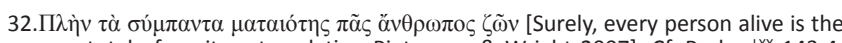
sum total of vanity - translation Pietersma \& Wright 2007]. Cf. Psalms ${ }^{\mathrm{LX}} 143: 4$ 2 Peter 2:18; also Ecclesiastes 1:2; 12:8 in T. Sol. B 8:2.

33.Cf. Proverbs 22:8a.

34.Cf. Ecclesiastes 1:2, 14; 2:11, 17; 3:19; 11:8.

35.Cf. Michel (1966:267).

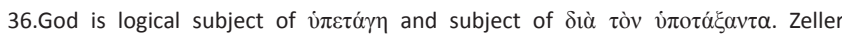
(1985:162) takes Adam as subject of the participle.

37.Or 'by him'; cf. Bauer et al. 2000, s.v. B dß. perils coupled with great toils. ${ }^{38}$ Recently, scholars drew attention to parallels between Romans 8:20 and Isaiah ${ }^{\mathrm{LXX}}$ 24:1-6. ${ }^{39}$ For example: 'The earth shall be ruined by decay' ( $\varphi \theta 0 \rho \tilde{\alpha}$ $\varphi \theta \alpha \rho \eta ́ \sigma \varepsilon \tau \alpha \imath \dot{\eta} \gamma \tilde{\eta}$ - Is. $\left.{ }^{\text {LXX }} 24: 3 a\right)$ as consequence of God's response to human sin, or:

The earth behaved lawlessly by reason of her inhabitants; because they have transgressed the Law, and changed the ordinances an everlasting covenant. Therefore a curse shall consume the earth, because those who inhabited it sinned ... (Is. ${ }^{\text {LXX }}$ 20:5-6).

These parallels are striking, especially if one recalls that Paul quoted Isaiah $^{\mathrm{LXX}} 25: 8$ in 1 Corinthians 15:54 and alluded to it in 2 Corinthians 5:4.

The ö $\tau$ clause in Romans 8:21 explains the content of the $\dot{\varepsilon} \lambda \pi i$ s. Since the creation is not meant to be subjected to purposelessness, what is anticipated? By introducing

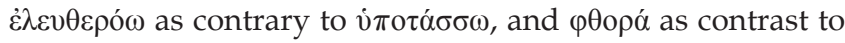
$\delta o ́ \xi \alpha$, it is clear that subjection will be turned into freedom, decay into $\delta$ ó $\xi \alpha$. In both cases Paul used a divine passive, but with a difference in tempus. With Adam's fall, God subjected the creation to futility in the hope that in future he will free creation itself from the enslavement to decay. Taking up the language of Romans 6:16-22, Paul depicts creation in terms of the metaphor of slavery. The use of the term $\varphi \theta 0 \rho \alpha$ sheds light on $\mu \alpha \tau \alpha i o ́ \tau\rceil s .{ }^{40}$ The futility of creation lies therein, that it is subjected to decay. In the end it leads nowhere. So severe are the deadly consequences of $\sin (\mathrm{Rm}$ 5:12). The future liberation is not only liberation from purposelessness and decay, but also freedom with a purpose. Keeping to the strategy of personifying creation, Paul states that, like a slave, creation will be liberated unto the freedom that comes with the $\delta$ ó $\xi \alpha$ of the children of God. The $\delta$ ó $\xi \alpha$ of the children who belong to God, entails their freedom and this freedom liberates them from the slavery caused by the breakdown of organic matter ( $\varphi \theta 0 \rho \alpha$ ). Paul draws a parallel between the

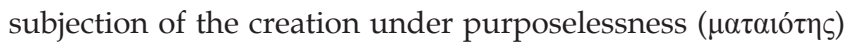

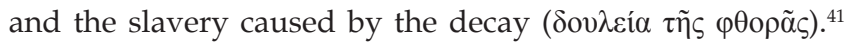
The movement is from enslavement to decay to liberation marked by the $\delta$ ó $\xi \alpha$ of the children of God, which entails their and creation's liberation from decay. Although Paul expects the liberation of creation, its return to a pre-Adamitic state of no decay, this change is subject to the revelation of the sonship of the children of God, their $\delta$ ó $\xi \alpha$. The question remains, however, to what does $\delta$ ó $\xi \alpha$ refer?

Paul starts the next section ( $R m$ 8:22-27) with two metaphors: childbirth and the adoption of children (cf. v. 15). He also expands on the topic under discussion in Romans 8:1821 , comparing the current state of the creation to that of the hidden children of God. Introducing his sentence in

38.(12) Et facti sunt introitus huius saeculi angust et dolentes et laboriosi, paucae autem et malae et periculorum plenae et laborum magnorum fultae. (13) Nam maioris saeculi introitus spatiosi et securi et facientes inmortalitatis fructu (text Vulgate).

39.Cf. Braaten (2006:145-147). Braaten's observations are complemented by those of Moo (2008:83-85).

40.Cf. Lietzmann (1928:85).

41.Cf. Fitzmyer (1993:505). 
Romans 8:22 with oif $\delta \mu \mu \varepsilon v$, he states something that is common knowledge to him and his addressees. The choice of

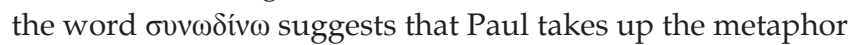
of childbirth. Presently, the whole creation groans and suffers severe pain as if in travail. The use of the composite verbs with $\sigma v v: \sigma v \sigma \tau \varepsilon v \alpha$ ç $\varepsilon 1$ and $\sigma v v \omega \delta i v \varepsilon \varepsilon$ is significant. The whole creation groans and suffers pain together with ... whom?

Presupposing what Paul has said in Romans 8:9-11 and $14-16$, verses $22 b-23$ give the answer. The children of God are included in the expectancy of creation, ${ }^{42}$ it groans and suffers together with those who, like Paul and the Romans, have a part of the $\dot{\alpha} \pi \alpha \rho \chi \eta \dot{~ o f ~ t h e ~ S p i r i t . ~ T h e ~ a n a l o g y ~ l i e s ~ i n ~}$ the parallel between childbirth and adoption. ${ }^{43}$ The creation is depicted as a mother groaning in birth pangs, and those who have the first portion of the Spirit as children expecting the fulfillment of their adoption. They also groan in the state of expectancy, expecting their adoption to come into effect. The last line of Romans 8:23 explains what is meant by the adoption as children - it implies the liberation of their bodies

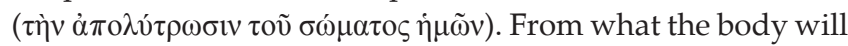
be liberated, can be inferred from the context. Those who are in Christ have already been liberated from $\sin (\mathrm{Rm}$ 6:18) and from being prisoners of war under $\sin (\operatorname{Rm} 7: 24 ; 8: 2)$, and the Spirit already lives in their bodies ( $\mathrm{Rm} 8: 5-11)$. The phrase $\theta v \eta \tau$ ̀̀v $\sigma \tilde{\omega} \mu \alpha$, which is used in Romans 8:11, also occurs in Romans $6: 12 .{ }^{44}$ What is meant by this? The body of those baptised into Christ's death is no longer under the power of $\sin (\mathrm{Rm} \mathrm{6:6)}$. They will become like the resurrected ( $\mathrm{Rm}$ 6:5) and shall live with him (v. 8), but until then, the body is still mortal ( $\theta v \eta \tau$ tov). Paul urges the addressees: they should not allow sin to reign over their mortal bodies (Rm 6:12), and they should not place their body parts like weapons in battle at the disposal of $\sin$ (v. 13). With the help of the Spirit, they should rather kill the acts of the body ( $\mathrm{Rm} \mathrm{8:13b).} \mathrm{The}$ liberation of the mortal body means that it will be made alive in such a way that its actions will no longer lead to death and its members no longer serve sin. It will no longer be subjected to corruption..$^{4}$ It is the liberation of the body from the possibility to leave the realm of grace and to revert to sin; to be ruled by sin. For those who are not in Christ, however, the wages of $\sin$ are death ( $\operatorname{Rm~6:23)~-~their~situation~stays~}$ unaltered.

As a short intermezzo, Romans 8:24-25 elaborates on غ̇ $\lambda \pi$ íc. Firstly, Paul makes two statements: 'for in hope we were saved' and 'hope that is seen is no hope'. The situation in which those who are saved live, is characterised by hope. ${ }^{46}$ Rephrasing the statement as a rhetorical question, he implies that nobody hopes for something that he or she sees. By choosing the present indicative for the following conditional sentence, Paul implies that the condition is fulfilled: under the

42.Cf. Lohse (2003:248).

43.On the parallelisms in Romans 8:21-23, cf. Jewett (2007:506).

44.Cf. the previous section entitled 'Romans 7:7-8:17 as presupposition for the interpretation of Romans 8:18-30'.

45.Cf. Michel (1966:270) and Jewett (2007:519).

46.Cf. Käsemann (1974:220). condition that what 'we' hope for cannot be seen, 'we' wait 'in patience', or to express it literally, 'through perseverance'.

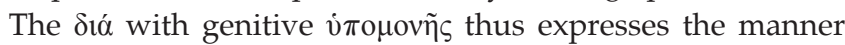
or way in which 'we' wait. ${ }^{47}$ The important question is: to what does the object of the hope, ô ov̉ $\beta \lambda \varepsilon \dot{\varepsilon} \pi \mu \mu \varepsilon v$, refer? It is something that cannot be seen presently and it must be the implied object of $\alpha \pi \varepsilon \kappa \delta \varepsilon \chi 0$ o $\mu \varepsilon \theta \alpha$. If we trace this verb, its objects

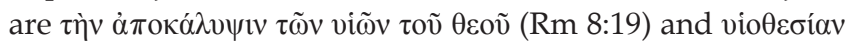
(v. 23b). The revelation of the still concealed sons of God, their vio $\theta \varepsilon \sigma i \alpha$, 'placing' $(\theta \dot{\varepsilon} \sigma ı \varsigma)$ as sons, is still invisible. The reason for this is that the revelation of the sons of God and their adoption as sons coincides with the liberation of their bodies (Rm 8:23fin). ${ }^{48}$ Hope thus designates the believers' current attitude of anticipating the full status they will have as children of God. Then their mortal bodies will have been made alive in such a way that sin has no effect on the body.

Setting in with 'likewise' ( $\dot{\sigma} \alpha \tilde{\tau} \tau \omega \varsigma)$, Paul recaps on Romans 8:22-23 in verses $26-27$ and reintroduces the topic $\pi v \varepsilon \tilde{v} \mu \alpha$ from verse $23 \mathrm{~b}$. The recurrence of the root of the verb $\sigma \tau \varepsilon v \alpha \dot{\zeta} \omega$ ( $R m$ 8:23) in the noun $\sigma \tau \varepsilon v \alpha \gamma \mu$ ó in verse 26 confirms that Paul takes up the theme of verse 23. He develops it further, though, presupposing the utterances he already made in Romans 8:9-11 and 15-16, and escalating the topic. ${ }^{49}$ Creation groans and those who belong to Christ groan, but they have the $\pi v \varepsilon \tilde{u} \mu \alpha \theta \varepsilon \circ \tilde{v}$ living in them. Those who did not receive the Spirit, those who were not baptised into Christ's death, and those who did not trust God's gospel are excluded. Paul comforts his addressees. They are not alone in suffering. The Spirit groans too. Paul explains in the following manner: They are sons of God; they have received a Spirit of adoption. During their present sufferings (Rm 8:18), whilst they wait in patience (v. 25) for the revelation of their sonship (v. 23), the Spirit comes their weakness to aid. Paul's wording is reminiscent of the Jesus tradition,,$^{50}$ but the role of the Spirit is somewhat different in the letter to the Romans. The Spirit assists the children of God during the prayers directed to God with inexpressible, wordless groans. Interceding, and thus mediating, between the supplicant and God, it comes to the aid of their incapacity to express themselves as they ought to - according to God's will. This weakness is due to the fact that they are still in their mortal bodies and suffering; they do not know which words to say in prayer. But God, who searches the hearts, ${ }^{51}$ recognises that the Spirit intercedes according to his will on behalf of the holy ones, the children of God.

The final section (Rm 8:28-30) starts with Paul's statement in verse 28 that he has recognised that all things work together ${ }^{52}$ for the good. He qualifies those who benefit in a double sense: from the human side it is those who love God, and from a

$47.0 n$ this use of $\delta$ io with a genitive, cf. Liddell et al. 1996, s.v. III 2.

48.Lietzmann (1928:84-85) opts for 'die Erlösung von unserem Leib'.

49.Cf. Lohse (2003:248).

50.Cf. LukeQ 12:11-12; Matthew ${ }^{\mathrm{Q}}$ 10:17-19; Mark 13:11.

51.On this topos, cf. the references of Zeller (1985:163).

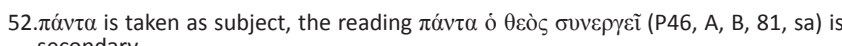
secondary. 
theological perspective it is those who are called according to God's purpose.

With ö $\tau$ in Romans 8:29, Paul introduces the reason for the claim that all things work together for the good. God knew them beforehand. But exactly for those he knew before, he decided ( $\left.\pi \rho \rho_{0} \rho i \zeta \omega\right)$ to have a form identical to the appearance ${ }^{53}$ of his Son. The consequence of God's decision to predetermine those, whom he called to have a form identical to the appearance of his Son, is that the resurrected will be

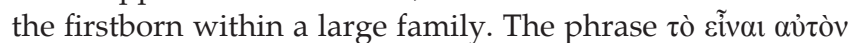
$\pi \rho \omega \tau$ tó $\theta \varepsilon \circ \tilde{v}(\operatorname{Rm~8:14,19)~vio\theta \varepsilon \sigma í\alpha ~(v.~15,~23)~\tau \varepsilon ́\kappa v\alpha ~} \theta \varepsilon \circ 0 \tilde{~(v . ~ 16-17, ~ 21) ~}$

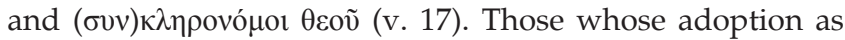
children of God will be revealed, are determined to become

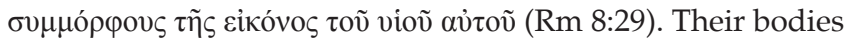

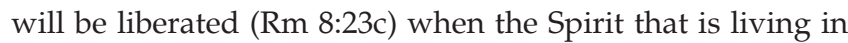
them will make their mortal bodies alive (v. 11). This means that their bodies as part of the creation will finally not be subjected to decay ( $\varphi \theta$ opó). It will then no longer be mortal ( $\theta v \eta \tau$ tó - Rm 8:11). The resurrection can, as in Romans 8:11,

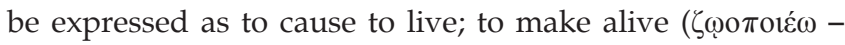
cf. 1 Cor 15:22, 45b). ${ }^{54}$ Paul hereby draws his argument to a close: the liberation of the prisoners of war, kept by sin in the body parts (Rm 7:24), comes to its full effect when the mortal body is made alive ( $\operatorname{Rm} 8: 11)$, when the captured body is set free (v. 23b), and when it gets the form of the appearance of the resurrected Son, who is the firstborn of the whole family of God's children. This is their future $\delta$ o $\xi \alpha$ to be revealed ( $\mathrm{Rm}$ 8:18). This is how they will be glorified with Christ ( $\mathrm{Rm}$ $8: 17 \mathrm{c})$. The liberation of the body from decay caused by sin has its positive correlation in the revelation of the $\delta$ ó $\xi \alpha$ of those already adopted as God's other children when it is made known that, in appearance, they are like God's own Son.

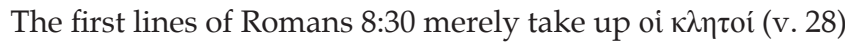

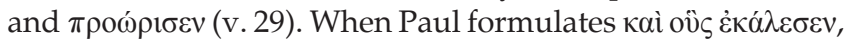

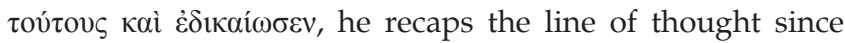
Romans 3:24-30 and prepares to return in verses 31-39 to the justifying effect of the death of Christ already expressed in

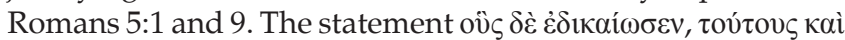
$\dot{\varepsilon} \delta$ ó $\xi \alpha \sigma \varepsilon v$ goes a step further: the ingressive aorist expressing that the process to honour those who are justified, but still live as mortal bodies, to increase their splendour, has begun..$^{55}$ In baptism they already received the sonship; it is already a present reality with God and will be revealed when their mortal bodies will be made alive. They will be conformed to the image which the Son himself is. ${ }^{56}$ Then they will be

53.Lohse (2003:253) understands cikôv as 'Wesen'. The word rather expresses correspondence between the object and the form it resembles; cf. Bauer et al. 2000, s.v. The interpretation with 'Gestalt' (cf. Zeller 1985:165) or 'image' (Fitzmyer 2000, s.v. The interpretation
1993:525) is more accurate.

54.If one reads Romans 8:29 in the light of verses 11 and 23c, it is likely that the idea of transformation so explicitly expressed in 1 Corinthians 15:51-52 (cf. 2 Bar. 51) is to be presupposed, as suggested by Zeller (1985:163).

55. Recently Harrison (2009:330) commented on the Roman ideal of glory and Paul's letter to the Romans. What could his understanding of eschatological glory have meant to the Christians in Rome? Harrison argues that the Pauline concept of glory given through divine grace inverted the Roman ideals of glory achieved by the ruling class.

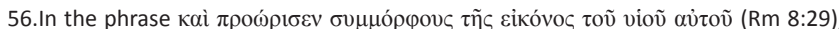

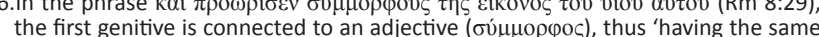
form of the image' (cf. Blass et al. $2001 \S 182$ ). The second genitive is dependent form of the image' (cf. Blass et al. $2001 \S 182_{1}$ ). The second genitive is dependent
on the preceding genitive and adnominal in function (cf. Blass et al. $\S 162,7$ ) 'the image belonging to the Son'. incorruptible as the image of the resurrected Son, regaining the $\delta$ ó $\xi \alpha$ lost through $\sin (\operatorname{Rm} 3: 23)$. It is in this state that they will be able to inherit the imperishable ( $\alpha \varphi \theta \alpha \rho \sigma i \alpha)$ kingdom of God (cf. 1 Cor 15:50), which is closely associated with his $\delta o ́ \xi \alpha(1$ Th 2:12).

\section{Romans 8:5-30 and cosmology?}

Because the Romans and Paul have the Spirit, they are already adopted as God's sons. Paul's expectancy is that this sonship will be revealed. This means that those who belong to Christ will become as the Son already is. The revelation of their sonship entails that their mortal bodies, in which they live now, will be made alive by the 'glory' of the Father, as the early Christians believed happened when the crucified Christ was resurrected (1 Cor 15:3-4; Rm 6:4). To put it in the words of 1 Corinthians 15:50-51, they will be changed. This is the $\mu \varepsilon \dot{\lambda} \lambda \lambda \sigma v \sigma \alpha \delta$ ó $\xi \alpha$ which Paul expects (Rm 8:18). There will be no more decay of the body; its parts will no longer be able to serve sin.

What does creation have to do with this? The human body is part of creation, part of what has been subjected to purposelessness ( $\mu \alpha \tau \alpha i o ́ \tau\rceil)$ ). As the mortal body of those having the Spirit will be made alive and changed, creation will also be freed from decay. The expected liberation of the body will inaugurate cosmic change. ${ }^{57}$ Adam's sinful deed affected the whole word by letting sin come into the world (Rm 5:12). In future, creation will be liberated by God from the slavery of decay with the same result as the liberation which lies in the glory of the children of God. Their mortal bodies will be made alive, free from decay and the deeds leading to death. Creation shares the expectancy of the children of God. The liberation of the children of God will lead to the liberation of creation. Paul moved from anthropology to his view on the future of creation. ${ }^{58}$

The liberation of the Adamitic human is inseparable from Christ. If one looks for the cosmic dimension in Paul's thought, one should realise that Romans 8:18-30 is preceded by an explication of how humankind is liberated from $\sin (\mathrm{Rm}$ $5: 12-8: 4)$ on the basis of the death and resurrection of Christ (Rm 5:1-11; 8:31-39). Christology encapsulates 'cosmology'. Paul's angle is that humanity has been acquitted (Rm 8:2) or created anew (2 Cor 5:17; Gl 5:16) in Christ.

\section{Conclusion}

Paul expects nothing less than the end of the mortality and decay of the human body which was caused by sin. Those who have the Spirit of God will be made alive, like God's own Son already is. And when their true form as God's adopted children is revealed, creation will be free of decay. Creation will be liberated from the bondage to decay when the sonship of God's children comes to its fulfillment. This implies that Paul does not expect the end of the material world. As God's creation, it is good. It will be freed from the effect of sin. For Paul, decay and immortality is a result of 57.Cf. Fitzmyer (1993:505-506).

58.Cf. Käsemann (1974:226). 
the sin that came with Adam's deed (Rm 5:18). Christ's act of righteousness will take this away. The gospel on the salvation of humankind has implications for creation that are only indicated in Romans 8:19-21. The letters to the Colossians and Ephesians would explore this line of thought further.

\section{Acknowledgements \\ Competing interests}

The authors declare that he has no financial or personal relationship(s) that may have inappropriately influenced him in writing this article.

\section{References}

Bauer, W., Danker, F.W., Arndt, W.F. \& Gingrich, F.W., 2000, A Greek-English Lexicon of the New Testament and other early Christian literature, 3rd edn., The University of Chicago Press, Chicago. http://dx.doi.org/10.7208/ edn., The University of Chicago
chicago/9780226028958.001.0001

Bertram, G., 1958, 'Апокарабокіа', Zeitschrift für neutestamentliche Wissenschaft und die Kunde der älteren Kirche 49, 264-270. http://dx.doi.org/10.1515/ zntw.1958.49.1.264

Blass, F., Debrunner, A. \& Rehkopf, F., 2001, Grammatik des neutestamentlichen Griechisch, 18th edn., Vandenhoeck \& Ruprecht, Göttingen.

Braaten, L.J., 2006, 'All creation groans: Romans 8:22 in light of Biblical Sources', Horizons in Biblical Theology 28(2), 131-159. http://dx.doi. org/10.1163/019590806X156091

Breytenbach, C., 2010a, 'Salvation of the Reconciled (with a note on the background of Paul's metaphor of reconciliation)', in Grace, reconciliation, concord: The death of Christ in Graeco-Roman Metaphors, pp. 171-186, Brill, Leiden. (Novum Testamentum Supplements 135).

Breytenbach, C., 2010b, "'Charis" and "Eleos" in Paul's Letter to the Romans', in Grace, reconciliation, concord: The death of Christ in Graeco-Roman Metaphors, pp. 207238, Brill, Leiden. (Novum Testamentum Supplements 135).
Cranfield, C.E.B., 1975, The epistle to the Romans, T\&T Clark, Edinburgh. (International Critical Commentary 1).

Dahl, N.A., 1951, 'Two Notes on Romans 5', Studia theologica 5, 37-48. http://dx.doi. org/10.1080/00393385108599711

Eschner, C., 2009, “'Die Hingabe des Sohnes 'für' uns alle": Zur Wiederaufnahme des Sterben-"'für"-Motives aus Röm 5:6-8 in Röm 8:32', in U. Schnelle (ed.), The Letter to the Romans, pp. 659-678, Peeters, Leuven. (Bibliotheca ephemeridum theologicarum lovaniensum CCXXVI).

Fitzmyer, J.A., 1993, Romans, Doubleday, New York. (Anchor Bible 33).

Harrison, J., 2009, 'Paul and the Roman ideal of glory', in U. Schnelle (ed.), The Letter to the Romans, pp. 329-369, Peeters, Leuven. (Bibliotheca ephemeridum theologicarum lovaniensum CCXXVI).

Hunt, C., Horrell, D. \& Southgate, C., 2008, 'An environmental mantra? Ecological interest in Romans 8:19-23 and a modest proposal for its narrative interpretation', Journal of Theological Studies 59, 546-579. http://dx.doi.org/10.1093/jts/fln064,

Jewett, R., 2007, Romans: A commentary, Fortress Press, Minneapolis. (Hermeneia).

Käsemann, E., 1974, An die Römer, Mohr Siebeck, Tübingen. (Handbuch zum Neuen Testament 8a).

Kuss, O., 1963, Der Römerbrief, Pustet, Regensburg.

Liddell, H.G., Scott, R. \& Jones, H.S., 1996, A Greek-English Lexicon, 9th edn. with rev. suppl., Clarendon Press, Oxford.

Lietzmann, H., 1928, An die Römer, Mohr Siebeck, Tübingen. (Handbuch zum Neuen Testament 8).

Lohse, E., 2003, Der Brief an die Römer, Göttingen, Vandenhoeck \& Ruprecht. (Kritischexegetischer Kommentar über das Neue Testament 4).

Mauersberger, A., 1956, Polybios-Lexikon. Bd. I, Akademie-Verlag, Berlin.

Michel, O., 1966, Der Brief an die Römer, Göttingen, Vandenhoeck \& Ruprecht. (Kritisch-exegetischer Kommentar über das Neue Testament 4).

Moo, J., 2008, 'Romans 8:19-22 and Isaiah's Cosmic Covenant', New Testament Studies 5, 74-89.

Pietersma, A. \& Wright, B.G. (eds.), 2007, A New English Translation of the Septuagint, Oxford University Press, New York.

Vögtle, A., 1970, 'Rom 8, 19-22: Eine schöpfungstheologische oder anthropologischsoteriologische Aussage?', in A. Descampes \& A. de Halleux (eds.), Mélanges bibliques en hommage au R.P. Béda Rigaux, pp. 351-366, Duculot, Gembloux.

Zeller, D., 1985, Der Brief an die Römer, Pustet, Regensburg. (Regensburger Neues Testament). PMCid:423851 